\title{
Inequality, Violence, and Ecology in Brazil
}

\section{Desigualdade, Violência e Ecologia no Brasil}

\author{
Maria Cecilia de S. Minayo' \\ MINAYO, M. C. S. Inequality, Violence, and Ecology in Brazil. Cad. Saúde., Rio \\ de Faneiro, 10 (2) : 241-250, Apr/fun, 1994.
}

This paper studies the articulation of three subjects - ecology, inequality, and violence - as interconnected components of reality, in such a way that each of the three interderes in the whole. At a time of increased ecological awareness, this paper shows that poverty, destination, and violence not only affect the environment, but that they are also responsible for the destruction of culture and life in society. Furthermore, as a cry for Nature, this increased awareness represents a struggle for life with dignity for all.

Key words: Ecology; Violence; Inequality; Social Policy

\section{INTRODUCTION}

"The more we extract things from Nature through the organization of labor, discoveries, and inventions, the more we are trapped into the insecurity of existence. It is not we who dominate things. They dominate us. And this occurs because certain human begins use things to dominate their fellows... If, as human beings, we wish to take advantage of our knowledge of Nature, we must add to it a knowledge of human society (Brecht, 1970)

Human society's most acute concerns for the end of this century can be read in Brecht's words: a. Is it possible, or ethical, to produce and consume at breakneck speed without considering the consequences for Nature and for those who produce? b. Can the poverty and destitution that affect $60 \%$ of humanity be tolerated as "natural selection" in the name of the right to property for those who detain power and wealth?

Ecological problems can only be dealt with by considering their planetary dimension and articulating the social and individual

${ }^{1}$ Departamento de Ciências Sociais, Escola Nacional de Saúde pública. Rua Leopoldo Bulhões, 1480, $9^{\circ}$ andar, Rio de Faneiro, RF, 21041-210, Brasil. issues that involve rethinking production, consumption, and reproduction. In Brazil, social inequalities are the greatest obstacle to the kind of solidarity that the ecological movement has proposed.

\section{ECALITY/INEQUALITY}

The report "Subsídios Técnicos para a CNUMAD-92" (TechNICAL Subsidies for UNCED-92) in the chapter "Rethinking the Development Model" calls our attention to the worsening of income inequalities and concentration of poverty in the less developed macro-regions of the world and at the domestic level in Brazil. The report concludes by stating that "the urban violence now characterizing major Brazilian cities is a pale foreboding of the terrible difficulties this country will have to face in the future"

(CNUMAD, 1991: 149).

While none of us questions that there is common ground between ecology, inequality, and violence, we should clarify to what extent and in what way these three concepts are articulated in causing alarmingly harmful effects on society.

To conceive of equality is to imagine a utopia that has fascinated humanity since time immemorial. In Genesis, the Bible calls 
attention to human beings common origin "in God's imager and likeness", as children of Adam and Eve", "inhabiting a land that is given to all to live in harmony with Nature". It is sin that creates discord between man and Nature, leading to misunderstanding among brothers and slavery as a form of human inter-relatioship.

Since the 18 th century, the doctrine of equality has evolved under the premise that differences in intelligence, race, color, gender, age, and nationality cannot justify inequalities based on privilege. When movements in favor of equality fail to respect differences, they become authoritarian and contrary to the very essence of human creation. When differences become the basis and justification for establishing inequalities, we are left with a society marked by expropriation and dehumanization (Dummont, 1966).

In a situation such as that of present-day Brazil, with profoundly disturbing inequality, it is because we have come to an extreme level of exacerbation and worsening of the concentration of wealth and economic expropriation that have made life in society unbearable for all.

Concentration of income has increased significantly in Brazil over the last thirty years. In 1989, the wealthiest $10 \%$ of the population earned $51.5 \%$ of the total national income, further aggravating a situation that was already scandalous in the beginning of the eighties, when the same $10 \%$ swallowed up $44 \%$ of the national "pie". Today, the top $1 \%$ of the social pyramid receive $15.9 \%$ of the income, the same share as the entire bottom $60 \%$ of the pyramid (Sabóia, 1993A).

The so-called "lost decade" (the 1980s) consolidated this income concentrating model as a style of development, with differential penalization of both sociopolitical regions and traditionally more exploited social strata within those regions. Some $53 \%$ of the country's poor are now concentrated in the Northeast. Furthermore, there are 45 million people (members of 11 million families) in poverty (that is, earning the minimum wage or less, some US $\$ 70$ a month) spread differentially throughout
Brazilian territory. Some $35 \%$ of these families live in destitution, earning one-fourth the minimum wage or less per capita. While this state of utter economic destitution affects all family members, the ones that suffer the most are the children, adolescents, and women. There are now some 32 million individuals from this social group in a state of poverty, and $43 \%$ of them are children under seven years old. Seventeen percent of Brazilian families are headed by women, the majority of whom make one-fourth the minimum wage or less (Sabóia, 1993; Simões, 1989).

The extreme concentration of poverty and wealth is reflected not only in distribution of income. It is also shown in the inequality of opportunities, ranging from malnutrition to the lack of social services and goods that are already available to the rest of Brazilian society. Indicators pertaining to nutrition, health, education, sanitation, and housing show that: 1 . Brazil has become a poverty belt and 2 . by the late 1980 s we had reached a level of urban poverty as serious as that which already existed in rural areas. The metropolization of poverty is now a terrible sign of the social situation we have reached. We are producing "handicapped" generations of citizens with limited possibilities for personal growth and development, who are unable to face the challenges of new stages of national development.

Since there is not public policy devoted to the social issue, the picture emerging in the early 1990s forebodes the following: an even greater increase in concentration of wealth (already one the worst in world; the only countries in the world that surpass Brazil in this dubious distinction are Sierra Leone, an impoverished African country, and Honduras, a poor, small nation in Central America); a trend towards a spurious wage structure disregarding workers' rights that had already been won under Brazilian labor legislation; a trend by companies to out-source services; an increase in both women's labor and the number of individuals (including children) that are employed in the number of workers in the tertiary sector, especially in underpaid professions with no social benefits (Sabóia, 1993). 
Poverty's persistent irreducibility and even its exacerbation may now be the biggest challenge faced by both society and government. For the population groups that are victims, this situation is a way of life, considered their destiny at some times and the object of organization for change at others. However, a recent alarming fact is that urban youth are reacting to this situation (which public policies in recent years have only made worse) with a desperate revolt expressed in the form of social violence (Lólio, 1989).

\section{VIOLENCE AND INEQUALITY}

The articulation of the concepts of violence and inequality is usually done in a very ambiguous way. It is customary to state that the poorer strata of the population are more violent and that they cause the social disorder and disturbances that assail the country. With rare exceptions, the mass media (newspapers and television) tend to reproduce and reinforce such prejudice. This tendency to blame the lower classes for prevailing social violence obeys an ideology justifying the "status quo". It idealizes the peace of social privilege and acquits the perpetuators of extreme exploitation. It attributes success in society to individual effort and explains the poverty of the rest as "laziness", "indolence", "lack of aspirations", or "social disease". This prevailing ideology sees the poor, above all Blacks, as the source of violence, that is, as "preferential criminals".

It is very difficult to explain violence. Philosophers, social scientists, ethologists, sociobiologists, and psychologists are among the specialists who have tried unsuccessfully to come to a definitive concept. There is no consensus on the issue; among other reasons, it is charged with socio-economic and political interests and cultural experiences and limitations, and because it articulates ethical, religious, and moral conceptions (Domenach, 1981; Joxe, 1981; Hegel, 1969; Costa, 1986; Pinheiro: 1979; 1984).

In this article we seek to repudiate the theories explaining violence as a biological attribute of human beings, which thus consider it ahistorical, apolitical, and nonsocial (Wilson, 1977). We also repudiate definitions that consider violence the "goddess of history", justifying it as a privileged political instrument for the advancement of humanity (Engels, 1981). In the same manner, we challenge the theories that explain violence exclusively in terms of economic causes, such as the revenge of the poor against the rich, as if each social group were not responsible for its own particular forms of violence, many of which go beyond class contours (Sorel, 1970; Engels, 1981; Oliven, 1982). We thus disagree with those who blame the increase in social violence on the weakness of the state, as if this institution were neutral, and as if it were able to detain a monopoly over truth to the benefit of all social sectors (Coelho, 1988), Finally, we do not accept theories explaining the violence in which we are living as the result of the country's last 40 years of social transition, as if this transition were not the results of the economic and political interests that are expressed in social relations (Merton, 1968; Huntington, 1968).

As we see it, the violence now assailing Brazilian society is a complex phenomenon with roots in society's own options for a kind of development that exacerbates unequal social relations and is expressed both in individuals (considering even their personal dispositions) and in groups, both in civil society and the state and in institutions as a whole and their components and proponents. Violence cannot simply be attributed to a group or class, because it always reveals a network of complicity, a given socio-cultural standard, an the level of historically constructed social awareness that provides the basis for defining limits for both tolerance and personal and social conflicts. Violence is present in both urban and rural social relations.

In order to operationalize our analysis, we have classified manifestations of social violence into four types. The first is structural violence, the type that sets apart in society the economically and politically dominant classes 
groups, and nations, a violence using laws and institutions to maintain a situation of privileges as if were natural. The second type is cultural violence, inseparable from structural violence, although it goes beyond the former. It includes male chauvinist domination, or "machismo", and its consequences, racism, nationalism, color prejudice, imposition by adults over other age groups, and all forms of cultural expression that diminish some human beings (and exalt others) and limit their life, creativity, and freedom. The third kind of violence as we see it is the delinquency present in all societies and which must be viewed in light of structural and cultural violence. While common sense tends to view delinquency independently as an external threat to society, it actually reveals the degree of exacerbation in relationships, conflicts, and contradictions, and in a very peculiar way shows the degree of disintegration of traditional values. In Brazil, delinquency reveals a deeply-ingrained male chauvinism, disrespect for individual and social rights, consumerism generated by materialist expectations of a society that promotes profit as a higher value, and demoralization of national authorities, governments, politicians, and elites.

Finally, a fourth kind of violence is resistance by socio-economically, politically, and culturally dominated classes and groups in the face of subjugation. Many authors have expounded on this theme, asking whether violence against oppression may not generate more violence. There is no simple answer to this question. At any rate, dominant groups, classes, and nations practicing violence against their subordinates as a "natural law" generally do so in the name of established power. Many authors justify forms of resistance such as liberation wars, strikes, rebellions, etc., as ways of establishing justice (Minayo, 1990).

In Brazil, social violence is clearly expressed in these four types. However, for the purposes of this analysis, the main objects of our attention are structural violence and delinquency. As we analyze inequalities, the data given in the study are identified objectively as the very expression of structural violence, that is: survival with an insignificant minimum wage or even less; children on the streets, begging, working, or involved in delinquency because of the utter inability of their families to support them; lack of schools or of conditions to attend school; medical and other health care that is inadequate or completely lacking; lack of basic sanitation; progressive loss of previously acquired social rights.

The population itself in outlying areas of major urban centers develop their own concept of violence, which is above all the state of abandonment to which they have been relegated by authorities, politicians, and elites. It is their state of expropriation and impotence which can be expressed as conformity, revolt, despair, or fatalism, which many members of popular classes define as "fundamental violence". This definition, which has been heard in field studies, contrasts with the dominant idea that considers poverty and destitution as causes of violence. In the minds of underprivileged members of society, poverty and destitution are not the cause, they are fundamental violence itself, the point of departure for constructing other expressions and for deconstructing the struggle for citizenship.

Structural violence is mainly articulated with delinquency, this elementary form of social protest and of disguising privileges and interests. Delinquency always reveals a complex social mesh where anti-civilizing interests representing a broad range of social groups prevail. In present-day Brazil, expressions of delinquency (above all as an urban phenomenon), head to a generalized feeling of fear and a search for scapegoats for crime, almost always with punishment for the poor, workers, and young people, mainly Blacks. In addition, delinquency generates a dangerous view in which "work never pays; crime pays"; that it is natural to transgress rights and to disrespect personal and social life; that to damage public property is an expression of healthy cleverness; that hardworking, honest individuals are "suckers"; that the rule is "to get the upper hand" in any and all situations; that Life is worthless, a quirk of fate. 


\section{MORBIDITY AND MORTALITY DUE TO VIOLENCE}

A myth that is widely subscribed to is that Brazilians are a peaceable people. However, our colonial history was funded on the slaughter, domestication, and enslavement of Indians and on African slave labor. Chronicals of the Imperial and Republican periods in Brazilian history are also marked by violence practiced by the holders of wealth, land, and power who for centuries have maintained and increased their privileges by violating the lives and rights of the majority of the population. Economic and political violence in Brazil has become consolidated as a relationship that is considered natural, and as a result, the worst form of expropriation practiced here sanctioned legally.

Crime in the form of delinquency has always existed in Brazil, just as in any other part of the world, as an intrinsic aspect of social relations, a chronic, universal problem troubling people's lives and denouncing how precarious human relationships are.

However, over the last two decades, social violence has emerged as a consecrated theme in the media, in studies by intellectuals, in political discourse, and in the confrontation of social movements. The health area reflects this concern: Ministry of Health statistics show that violence now plays an increasingly important role as a factor for morbidity and mortality (Minayo \& Souza, 1993).

While infectious and parasitic diseases accounted for $46 \%$ of all deaths in Brazil in 1930 , by 1985 they had been reduced to only $7 \%$ of the total. On the other hand, violence, which accounted for only $3 \%$ of all deaths in 1930 , had increased to $12 \%$ of all deaths by 1985 , having reached third place in overall mortality in the country (Prata, 1991). Of course, these highly aggregate data should be viewed in light of the peculiarities of given regions and their respective social formations, since that is where the overall process takes on specific contours. Still, Prata's studies (1991) show that violence as a cause of death has increased in all regions of
Brazil, in the hinterland as well as in major metropolitan areas. The following is an attempt to sum up this trend.

\section{Violence in Rural Brazil}

Although urban violence is what has most shocked us recently, whether this be due to the city's hegemony over the country, its numerical dimension, the seriousness of its significance, or its opinion-forming role (represented here by the media), current violence in rural Brazil is nevertheless frightening. Rural violence articulates old and new structural conflicts marking social relations in the national land tenure scenario.

In recent decades there have new forms of violence in land conflicts. This is clear from their systematic, generalized nature and their continuous, excessive use, generating a steady and uncontrollable increase in rural crime. Violence in rural areas has no doubt been an inherent strategy for further concentration of land tenure.

According to data from the former MIRAD (Ministry of Land Reform and Development), 3,000 land conflict situations were reported from 1985 to 1987 . These conflicts were marked by the use of force and physical and moral harassment, up to and including armed assault and battery and homicides.

According to this same source, from 1985 to 1987 there were 654 deaths resulting from land conflicts in Brazil. In other words, there was a fatal victim every day and a half. Twothirds of those killed were rural workers. While there were murders in all states of Brazil, the majority of the homicides due to land tenure problems occurred in the North, Northeast, and Middle-West.

As in major metropolitan regions, the rural population's fear and panic are indirect proportion to the impunity associated with massacres of rural workers, including all kinds of bodily injury, torture, rape, decapitation, and lynchings. Recent land conflicts have also consolidated organized crime, including groups of outlaws, gangs, 
and squads infesting the Northeast, MiddleWest, and Amazon. The victms are nearly always rural workers and Indians or professionals representing or defending them, such as lawyers, teachers, and priests.

We are faced with new forms of gangsterism both in the country and the city. In the countryside, traditional violent strategies (crimes of honor, family feuds, blood vendettas) have taken second stage to current forms of violence caused by land occupation by land-concentrating interests representing big business.

"Government intervention in rural areas in recent years has allocated an enormous volume of tax incentives and subsidies and has done concessions to and sale of public lands rather than democratizing access to land. In so doing, it has aggravated the concentration of both land tenure and public resources devoted to farming and livestock-raising”(Almeida, 1988)

The result of this new kind of latifundium system is still expressed by the traditional forms of labor exploitation, but it also disrupts the small-farmer economy and further aggravates the expulsion of huge contingents of rural workers from the land they cultivate. Added to this situation ate the conflicts occurring in the gold-prospecting areas. In 1986, the extinct MIRAD registered 400 thousand gold prospecters and 64 conflicts involving them.

One of the results of land conflicts is the exodus of rural workers to the metropolitan regions, aggravating urban problems, leading to mobility process with a problematic demographical configuration. There is an increasing trend toward concentration of families in camps and/or land invasions, with an increasing potential for social tension. In 1986, there were 18,478 families located in 99 camps in the South of Brazil (Almeida, 1988).

According to estimates by the Ministry of Labor quoted by Almeida (198), there were five million rural workers in 1986 in conflictive situations caused by lack of observance of labor legislation and illegal use of measures to immobilize the labor force.

As we can conclude, violence in the rural areas of Brazil still has a structural contour, taking workers' lives, impeding the traditional cultivation of staple crops and paving the way for the institutionalization of organized rural banditry. While this violence is different in some ways from that in big cities, it is inspired by the same logic, a landconcentrating, elitist logic.

Studies by Grzybowski (1987) and Almeida (1988) are restricted to violence due to land tenure motives, since it is strongest expression of domination by and in favor of inequality in the rural areas of Brazil.

However, one should add to all of this the problems in border areas, such as the drug traffic and smuggling of weapons, merchandise, precious gems, and cars that are responsible for an atmosphere of violence resulting in murders. Furthermore, real working conditions in the country are responsible for an unmeasurable amount of work accidents and pesticide poisonings (we say unmeasurable in the sense that such accidents are not notified officials, although they are observed empirically).

\section{Urban Violence}

Like violence in the country, violence in the big has also changed its profile, having become a major cause of mortality. Statistics show that in the metropolitan regions, external causes are particularly significant among youth: $46.5 \%$ of deaths in the 5-14 year age bracket and $64.4 \%$ of those in the 15-29 year age bracket are due to violence, which thus ranks first as the cause of death in these two age bracket. In the 30-49 age bracket, external causes account for $23.7 \%$ of the deaths, second only to cardiovascular diseases (Szwarcwald, 1989; Radis, 1990) "Extrenal Causes" is a concept used by WHO to classify morbidity/mortality due to accidents, homicides, suicides, and poisonings.

Among the causes of death, note that traffic "accidents" vie with homicides, the former accounting for some $23 \%$ of mortality due to 
violence in the big cities. Work "accidents" are undernotified, and the limited knowledge we have of then is evidence of the prevaiting neglect and exploitation in work relations, notification, and programs for prevention rehabilitation.

What is deeply disturbing today, in addition to all the other problems, is the significantly growing trend towards homicides with some specific characteristics in the statistics on mortality. The first such characteristic is the excessively high male mortality rate, at a ratio of four men to one woman. The second characteristic is the risk group most vulnerable to homicides: young people between 15 and 29 years of age (the productive age, the future of our country!), where the male/female ratio is eight to one.

While they do not encompass the whole meaning of the process denounced by the process denounced by the data, it is important to call attention to some manifestations of urban violence, which we sum up here under four points: 1 . the changes in the profile of so-called "common" crime; 2. the phenomenon of Street Boys and Girls; 3. organized crime; and 4. "whitecollar" crime.

With regard to the first point, we presently see in the cities a change in the standard for "vagabond" ["malandro" in the original Portuguese-T.N.] "thief", and pickpocket" as figures that stand out and suffer discrimination, as protagonists of diffuse, covert practices, yet not foreign to "getting by", where the border between delinquency and work becomes hazy. On the one hand we see a situation of economic squeeze for the poor with almost no legal way out, and on the other, for the better-off, an ideology of getting the upper hand at every opportunity. This has helped shrink the limits on many people's scruples in relation to property, be it public or private. Methods of appropriation are highly differentiated. Such behavior, which can hardly be categorized as delinquency (thanks to its covert, subreptitious character), distinguishes in everyday life the limits between inequality and legality.
The second point is reflected in the current institution of Street Boys and Girls, a shocking paradigmatic situation stemming from the effects of economic and social violence and its articulation with delinquency. The process of children being expelled from the family nucleus onto the street must be understood first (but not only) as a movement of the poor for survival. It creates a new space for informal labor and begging, fertile ground for delinquency, where organized crime recruits its "temporary help" [or "bóias frias" in the original Portuguese, an allusion to the "cold lunchers", or temporary migrant day laborers in the current Brazilian agricultural system T.N.].

Condemned to being what society has made of them, these children and adolescents, victims of an exclusive economic system, also end up as victims of extermination, fights between street "gangs", and their own breaches of the law. Since 1988, the hideous crime of extermination has taken the lives of three children a day in Brazil: poor, Black, and young, they swell the statistics on homicide in the major metropolitan regions.

The murder of children is now perhaps the biggest challenge to the quality of development in Brazil. We have become accustomed to seeing our city squares full of beggars; we have become accustomed to seeing the poor and outcast take up residence under our bridges and viaducts; we have become accustomed to the sad spectacle of children trying to eke out a living at stop lights... but perhaps we have never asked ourselves what this dehumanizing process has to do with us.

The third point mainly reflects a change in the forms of traditional violence. According to Paixão (1990), it was in the 1960s that crime began to be organized, and over the last decade this organization came to be centered in the drug traffic, with an entrepeneurial character that replicated the very process of accumulation using conservative methods and guns. The drug traffic is an international network, sweeping the country from North to 
South, permeating both city and country, including powerful groups that ramify within both legal and illegal institutions and have as the tip of their iceberg the marijuana pushers located in slums and outlying urban areas.

While this articulated, lucrative network permeates powerful sectors hiding in venerable institutions, it does its greatest damage among youth, particularly among lower-income children and adolescents, who are easily enticed by the immediate advantages they are offered. In the groups that are formed, the idea of easy money, the myth of the "bandit hero", and enchantment with the handling of guns all go together with their disenchantment over poverty, scarcity, and lack of opportunities. At an age where they are attracted by the forbidden, by adventure, and denial of tradition as part of intrapsychic development, many of these young people end up arrested or swelling the homicide statistics as burglars, kidnappers, protagonists in fights, and "burned files".

According to Zaluar (1990a), a "bandit" rarely lives to be 25 years old.

Organized crime today does not only deal in illicit drugs; it is organized to smuggle weapons and stolen cars and hold kidnappings and bank robberies and other kinds of activities, including legal and political one. In the fourth place, urban reality now raises the problem of corruption in the public sphere with the complicity of the private sector.

While according to philosophers the issue of corruption is implicit to power, it frightens us today because of the way it has reached such venerable institutions as the court system, the legislature, and political forces and institutions of a social nature.

Perhaps in the economic crisis in which we are living, the so-called "white-collar crimes" lay bare our ethical and moral crisis more than anything else, our loss of social cohesion, the crumbling of our traditional values.

Scholars have shown over the course of history that violence is one of the forms of social expression. It should be thought of like this when we seek ways to escape from its grip. Violence is never a solution to violence, either in the country or the city. The principles for overcoming violence are to be found in the search for social and human values built by the community, above all in the search for basic individual and group rights in overcoming the circle of poverty. History therefore shows that it is possible to move in a positive evolution in terms of relationships between human beings themselves (and with nature), but that it is equally possible to slip back even further. What is the limit?

\section{ECOLOGY/INEQUALITY/ VIOLENCE}

A concept created by a German naturalist in the late 19th century, "Ecology" in etymological terms means "the science of household management". Considering the very planet we inhabit as our home, ecology, through the conservationist movements, has worked for the preservation and equilibrium of the environment. Progress (as humanity has achieved it) and the ideology of domination of nature at may cost have come to threaten life on the planet and the survival of humankind.

However, the worldwide outcry over the threat to the environment has been bolstered by voices placing at the center of the ecological debate the degradation of human beings, whether by the total materialization and massification of their lives or the degeneration of social relations and subjectivity. We have come to the certainty that the biggest challenge of our time is the ethical and political articulation between social relations, environment, and subjectivity with new foundations.

In contemporary Brazilian reality, the inequalities that have become structural violence and that are materializing in delinquency are perhaps the most striking real and symbolic fact for our ecological conscience. As Ignacy Sachs (1987) reminds us as he defends the concept of "ecodevelopment", we are on the high seas in a slave ship. On the upper deck there are parties, 
masked balls, and banquets, while in the hold the slaves scream out, rebel, and die, threatening the wealth of the powerful. Despite the orchestra's harmonious chords, the rich cannot forget that we are all in the same boat and that we will pull into the same port, guided by them. Otherwise, we will all shipwreck. Therefore, an ecosocial approach takes as its point of departure the observation that environment problems are not complementary to but rather in conflictive opposition with inter-human relationships and relationships with nature. Extreme inequalities, structural violence, and environment degradation are intrinsically articulated.

However, we cannot agree with the incrimination of the poor as responsible for the destruction of the environment. While it is true that they, too, are predators, we believe that their responsibility is limited to actions they practice in the struggle for survival.

Much to the contrary, they are the victims of the metropolization of poverty and the degradation of social relations in the country. The heavier social burden for them means creating an increasingly degenerated environment due to increased population density with no compensation in the form of favorable social policies.

It is the poor who live in unhealthy housing with no basic sanitation or garbage collection, who drink polluted water, and who die in landslides and floods long before they reach the mean age predicted by the national life expectancy statistics. It is the poor who live in makeshift land settlements, under bridges and viaducts, in the slums or in the outskirts of the cities, around the factories, suffering the most from air and sound pollution. And when sanitation and infrastructure services finally reach such areas, it is the poor who are thrown out by the real estate speculators.

Furthermore, the poor are the victims of hospitalization with lack of sanitation as an associated cause. They are also the victims of the proliferation of anthropic fauna in urban and rural areas, such as rats, scorpions, hematophagous bats transmitting rabies, mosquitos transmitting dengue fever and malaria, flies, and other animals that proliferate in garbage and filth.

A new "ecosophy" has dethroned humans as owners of Nature, but it has not eliminated their role as protagonists for life on Earth as awareness, desire, and will.

In synthesis, we have come to a crucial crossroads today: either we accept the chronification of huge contingents of human beings in a situation of violence, poverty hunger, and physical and mental degeneration as the largest anti-ecological spectacle of our times; or we accept the challenge to rethink social and political relations that generate and increasingly deteriorate the lives of the poor. Thus, we should not accept that History is dead (and how terrible this would be in Brazil, mummifying us in the scandalous social situation we find ourselves in!). Rather, it is up to us to face the challenge of directing History's course toward building an ecologically healthy society, one that is humanly more just, remembering that "justice", according to Aristotle, is the qualitative meaning of equality.

\section{RESUMO}

\section{MINAYO, M. C. S. Desigualdade, Violência e Ecologia no Brasil Cad. Saúde Públ., Rio de Janeiro, 10 (2)A: 241-250, abr/jun, 1994.}

Este artigo trata da articulação dos três temas, Ecologia, Desigualdade e Violência como componentes interligados de uma realidade, de tal forma que existe uma interferência de cada um no conjunto.

No momento em que há um despertar da consciência ecológica em relação ao ambiente, este texto vem mostrar que a miséria, a pobreza e a violência não só afetam-no mas são responsáveis pela destruição da cultura e da convivência. $E$ dentro de um grito pela natureza, salve-se também a vida com dignidade para todos. Palavras-Chave: Ecologia, Violência; Desigualdade; Políticas Sociais. 


\section{REFERENCES}

ALMEIDA, A. W. B., 1988. Conflitos sociais no campo e cidadania. In: Em julgamento a Violência no Campo (E. Tajardo, org.), pp. 132-147, Rio de Janeiro: Fase.

BRECHT, B., 1970. L'achat du Cauitre. Paris: Maspero.

COELHO, E. C., 1988. A criminalidade urbana violenta. Dados, Revista de Ciências Sociais, 31: 145-184.

COSTA, J. F., 1986. Violência e Psicanálise. $2^{\mathrm{a}}$ ed., Rio de Janeiro: Graal.

CNUMAD (Conferência das Nações Unidas para o Meio Ambiente e o Desenvolvimento), 1991. Subsídios Técnicos. Edição Especial. Rio de Janeiro: CNUMAD. (Mimeo.)

DOMENACH, J. M., 1981. La Violencia in La Viole: ia y sus Causas. Paris: UNESCO.

DUMONT, L., 1966. Homo Hierarchicus et Homo Aqualis. Paris: Gallimard.

ENGELS, F., 1981. Teoria da Violencia. São Paulo: Ática.

GRZYBOWSKY, C., 1987. Caminhos e Descaminhos dos Movimentos Sociais no Campo. Petrópolis: Vozes/Rio de Janeiro: Fase.

HEGEL, J. F., 1969. Filosofia del Espiritu. Buenos Aires: Claridad.

HUNTINGTON, S., 1968. Political Order in Changing Society. New Haven: Yale University Press.

JOXE, A. (Org.) 1981. La Violencia y sus Causas. Paris: Unesco.

LÓLIO, C. A. (Org.), 1989. Investigação sobre a magnitude e tendências da mortalidade de adolescentes no Brasil: 1977-1985. São Pauloa: Opas. (Mimeo.)

MERTON, R. R., 1968. Sociologia Teoria e Estrutura. São Paulo: Mestre Jon.

MINAYO, M. C. S., 1990. Bibliografia Comentada da Produção Científica Brasileira sobre Violência e Saúde. Rio de Janeiro: Escola Nacional de Saúde Pública. (Série Panorama, 2)

MINAYO, M. C. S. \& SOUZA, E. R., 1993. Violência para todos. Cadernos de Saúde Pública, 9: 65-78.
MS (Ministério da Saúde, 1985. Estatísticas de Mortalidade. Brasil. Brasília, DF: Ministério da Saúde.

OLIVEN, R. G., 1982. Violência e Cultura. Rio de Janeiro: Vozes.

PAIXÃO, A. L., 1990. aA Violência urbana e a sociologia. Violência: Religião e Sociedade, 15: 68-82.

PRATA, P. R., 1991. Desenvolvimento, Desigualdade, Saúde e Mortalidade. Rio de Janeiro: Fiocruz. (Documento Técnico ECO 92) (Mimeo.)

PINHEIRO, P. S., 1979. Violência de Estado e classes populares. Dados, 22: 05-24. , 1984. Escritos Indignações. São Paulo: Brasiliense.

RADIS (Reunião, Análise e Difusão de Informação sobre Saúde), 1990. Regiões metropolitanas: Violência na vida e na morte. Dados, $\mathrm{n}^{\circ} 14$.

SABÓIA, J., 1993. Distribuição de renda e pobreza metropolitanas no Brasil. In: Os Limites da Exclusão Social: Meninos e Meninas de Rua no Brasil (M. C. S. Minayo, org.), pp. 31-64, São Paulo: Hucitec.

SACHS, I., 1987. A questão alimentar e o ecodesenvolvimento. In: Raizes da Fome (M. C. S. Minayo, org.), $3^{\text {a }}$ ed., pp. 135-141, Rio de Janeiro: Vozes.

SIMÕES, C. C. J., (Org.), 1989. Perfil Estatístico de Crianças e Mães no Brasil: Mortalidade Infantil e Saúde na Década de 80. Rio de Janeiro: IBGE.

SOREL, G., 1970. Réflexions sure la violence. Paris: Minuit.

SZWARCWALD, C. L., 1989. Mortalidade por Causas externas nas capitais das grandes regiões metropolitanas brasileiras - 19771985. Rio de Janeiro: Fiocruz. (Mimeo.)

WILSON, E. ${ }^{\circ}, 1977$. Human sociobiology: A preface. In: Essays in Human Sociobiology (E. O. Wilson, ed.), pp. 1-50, New York: Reven Press.

ZALUAR, A., 1990. Teleguiados e chefes: Juventude e crime, Violência: Religiões e Sociedade, 15: 54-68. 